\title{
Role of Udvartana, a diurnal Ayurveda practice in the prevention of diabetes mellitus
}

\author{
Aditya Bhat ${ }^{1}$, Geetha Kumari $\mathrm{S}^{2}$ \\ ${ }^{l}$ Associate Professor, Department of Kaumarabhritya,${ }^{2}$ Associate Professor, Department of Swasthavritta and Yoga, \\ Shree RMD Ayurved College and Hospital, Wagaldhara, Gujarat, India.
}

\begin{abstract}
Diabetes is among the most common lifestyle disorders of the modern era. The current approach towards its prevention and management is largely based on diet and lifestyle modifications. As increased body weight and serum lipids have been implicated in the risk factors of diabetes, measures to reduce them have a significant role to play. Udvartana described as a diurnal practice for health maintenance in Ayurveda plays an important role in the prevention and management of diabetes. Clinical studies have shown that Udvartana helps in reducing body weight as well as serum lipids. A review of the role of Udvartana in the prevention and management of diabetes is attempted here.
\end{abstract}

Keywords: Diabetes; Udvartana; Body weight; Serum lipids.

\section{Introduction}

As per W.H.O. data, the number of people with diabetes in the world has increased from 108 million in the year 1980 to 422 million in the year 2014. The worldwide prevalence of diabetes among adults over 18 years of age has increased from $4.7 \%$ in 1980 to $8.5 \%$ in 2014 . Diabetes is now emerging as a major cause of blindness, kidney failure, heart attacks, stroke and lower limb amputation. In 2016, an estimated 1.6 million deaths around the world were directly caused by diabetes. WHO estimates suggest that diabetes was the seventh leading cause of death in 2016. A healthy diet, regular physical activity, maintaining normal body weight and avoiding tobacco are deemed to be the ways to prevent or delay the onset of type 2 diabetes. Simple lifestyle measures have been proved to be effective in preventing or delaying the onset of type 2 diabetes. (1)

Udvartana is a diurnal practice recommended by Ayurveda for the maintenance of health. It is a type of massage of the body with the powder

of herbal and some non-herbal materials. This is an external and noninvasive procedure that can be done over a local area of the body or the whole body. This practice is also used as a therapeutic measure to treat a few disorders in Ayurveda. It is mostly used to treat a variety of lifestyle disorders like diabetes, obesity and certain skin disorders. Mostly, Udvartana is prescribed for management of lifestyle diseases in Ayurveda. Udvaratna is also used as a cosmetic procedure as it improves the health of skin. There are different practices of Udvartana depending on the type of materials used and the intention for which it is used. However, there are not many studies available to validate the effects of Udvartana.

eISSN: 2523-6709

pISSN: $2523-6695$

DOI: $10.31878 /$ ijcrpp.2019.34.04

\section{Discussion}

Diabetes mellitus is a group of metabolic disorders characterized by raised blood sugar due to defects in insulin secretion, action or both.(2) The factors behind the outbreak of this epidemic of global type 2 diabetes include overweight and obesity, sedentary lifestyle and increased consumption of unhealthy diets containing high levels of red meat and processed meat, refined grains and sugar-sweetened beverages.(3) It is established by studies that weight reduction helps delay onset of diabetes in prediabetics and helps in reducing the overall risk of it. Further, weight reduction has been found to improve glycemic control.(4) Hence it appears that weight management plays an important role in the prevention of diabetes. There are several measures to reduce the weight of the body out of which following a low-calorie diet and regular physical activity are popular and widely practiced ones. However many individuals find it difficult to adhere to these for long and hence noncompliance is common. People around the world have been seeking complementary and alternative medicines to tackle diabetes. It is estimated that complementary and alternative medicine (CAM) is used by $80 \%$ of the world population for primary health care.(5)

Udvartana which is described in ancient Ayurveda texts has been said to produce a loss of fat, maintain integrity of tissues and preserve the health of skin. It helps decrease kaphadosha and medodhatu which according to Ayurveda are increased in diabetes.(6) Clinical evidence suggests multiple catabolic benefits of udvartana on body fat. In a study, significant decrease in physical parameters such as body weight, body mass index, waist circumference, hip circumference, waist-hip ratio and skinfold thickness was observed due to udvartana. A significant reduction in psychological parameters such as score of stress inventory scale was observed. A significant improvement in quality of sleep in study group was found.(7) These findings suggest udvartana reduces the body fat as well as the stress.

Correspondence: Dr. Aditya Bhat, Department of Swasthavritta and Yoga, Shree RMD

Ayurved College and Hospital, Wagaldhara, Gujarat, India. E-Mail: adityabhat24@gmail.com 
Clinical evidence suggests that Udvartana helps in reducing tissue fat as well as serum lipids. Udvartana has been found to reduce central obesity significantly. A significant reduction in serum lipids along with an increase in HDL cholesterol by Udvartana has been observed in studies.(8) Thus Udvartana has a compound influence on body fat as well serum lipids. This gives the dual advantage of preventing diabetes as well as its vascular complications. The exact mechanism of action of udvartana is not understood. Ayurveda texts explain that Udvartana improves the metabolic activities in the tissues. The effect of udvartana could be due to its action on the enzymes regulating lipid breakdown. The powders of herbs commonly used for Udvartana may stimulate the lipolytic enzymes. Also, the action of brisk rubbing of powder over the skin may produce a mechanical effect on the receptors of the skin. Even though it is a non-invasive procedure it exerts its systemic action as evidenced by its effect on lowering the serum lipids. This shows udvartana may stimulate lipid catabolism throughout the body.

Ayurveda texts mention that Udvartana relieves obstructions in the microchannels of the body (9). This explanation points towards the effect of Udvartana in improving the microcirculation as many practitioners of Ayurveda use Udvartana to treat vascular disorders. Skin disorders are frequently encountered in diabetes with cutaneous infections, xerosis and inflammatory skin diseases being the commonest.(10) In Ayurveda texts Udvartana has been claimed to exert a positive influence on the health of the skin. However, studies to show its effect on skin are not available.

\section{Conclusion}

Diabetes is a disease that needs a holistic approach for its prevention and management. Simple lifestyle modifications like Udvartana can play a crucial role in this regard. Udvartana offers multiple health benefits that suit the demands of prevention and management of diabetes. Preliminary studies carried out on udvartana so far suggest the potential role Udvartana can play in reducing the excess body weight and serum lipids which have been identified as risk factors of diabetes. Other possible benefits of Udvartana like its effect on vascular system and skin are also complimentary in the care of diabetes. However, there is a need for large sample clinical studies to validate the effects of Udvartana. Studies involving large groups of people with diabetes and those with risk of diabetes should be carried out to evaluate the role of udvartana in the prevention of diabetes. Also, as many substances are used for Udvartana the effect of individual substances

should also be evaluated. However, as it involves the usage of different substances for rubbing over the skin, an adverse reaction in the skin is reported in some individuals. Also, caution should be exercised while using Udvartana in people with broken skin.

\section{References}

[1] World Health Organization (W.H.O.), diabetes factsheet, 30 October 2018, available from https:// www.who.int/news-room/fact-sheets/detail/diabetes
[2] A. Bhattacharya, aetiology and pathology of type 2 diabetes mellitus, The Pharmaceutical Journal,1 Aug, 2009.

[3] Yan Zheng, Sylvia H. Ley \& Frank B. Hu, Global aetiology and epidemiology of type 2 diabetes mellitus and its complications, Nat rev Endocrinol. 2018 Feb;14(2):88-98

[4] J P H Wilding, The importance of weight management in type 2 diabetes mellitus, Int j Clin Pract, 2014 Jun, 68(6):682-91.

[5] Wen-Chin Yang, Srinivas Nammi, Per Bendix Jeppesen and William C. S. Cho, Complementary and Alternative Medicine for Diabetes, EvidenceBased Complementary and Alternative Medicine, vol.2013, Article Id831068, 3 pages, 2013.

[6] Acharya Vagbhata, Dinacharya adhyaya, Sutrasthana, Astanga Samgraha of Vagbhata, Translated by Prof. K.R. Srikanth Murthy, Vol.1, Ninth edition, Chaukhambha Orientalia, Varanasi, 2007.

[7] Vivek Kumar Mishra, Dilipkumar K. V and Neha Mishra, Role of udvartana on psychophysical parameters of healthy volunteers - a randomized controlled trial, World journal of pharmacy and pharmaceutical sciences, Vol 5, Issue 03, 2016.

[8] Parul Sharma, Ved Bhushan Sharma, A clinical study to evaluate the effect of lekhan basti, udvartana and navak guggulu in the management of Obesity vis-à-vis Sthoulya, International Ayurvedic Medical Journal, Volume 3; Issue 2; February-2015.

[9] Acharya Sushruta, Anagatabadhapratishedham adhyaya, Sutrasthana, Sushruta Samhita of Sushruta, Edited by Vaidya Jadavji Trikamji Acharya, Chaukhambha orientalia, Varanasi, 2014.

[10] Michelle Duff, Olga Demidova, Stephanie Blackburn, and Jay Shubrook, Cutaneous Manifestations of Diabetes Mellitus, Clin Diabetes, 33(1): 40-48, Jan 2015. 